\title{
PERBEDAAN TINGKAT KEBUGARAN JASMANI MAHASISWA FAKULTAS ILMU KEOLAHRAGAAN UNIVERSITAS NEGERI MEDAN DENGAN SEKOLAH TINGGI OLAHRAGA DAN KESEHATAN BINAGUNA ANGKATAN 2015
}

\author{
Oleh \\ Agus Salim Samosir ${ }^{1}$, Michael Thomson ${ }^{2}$, Deni Rahman Marpaung ${ }^{3}$ \\ ${ }^{I}$ Fakultas Ilmu Keolahragaan Universitas Negeri Medan \\ ${ }^{2}$ Fakultas Ilmu Keolahragaan Universitas Negeri Medan \\ ${ }^{3}$ Fakultas Ilmu Keolahragaan Universitas Negeri Medan \\ Email: agus.samosir17@gmail.com
}

\begin{abstract}
Abstrak
Penelitian ini bertujuan untuk mengetahui perbedaan tingkat kebugaran jasmani mahasiswa Fakultas Ilmu Keolahragaan Universitas Negeri Medan dengan Sekolah Tinggi Olahraga Dan KesehatanBina Guna Angkatan Tahun 2015. Penelitian ini dilaksanakan di Fakultas Ilmu Keolahragaan Universitas Negeri Medan Jln. William /skandar Psr. V- Medan dan Sekolah Tinggi Olahraga dan Kesehatan Bina Guna Jln. Alumium Raya No,77 Tj. Mulia-Medan 20241. Populasi dalam penelitian ini adalah seluruh mahasistwa Fakultas Ilmu Keolahragaan Universitas Negeri Medan dan Sekolah Tinggi Olahraga dan Kesehatan Binaguna yang berjumlah 537 orang. Sampel dalam penelitian ini adalah 50 orang yang masing-masing 25 orang dari Stok dan/25 dari Unimed, Teknik-pengambilan sampel dengan menggunakan total sampling dan disaring dengan kriteria yang telah ditentukan oleh peneliti. Teknik analisis data yang digunakan adalah dengan mencari uji normalitas, uji homogenitas, mean, simpangan baku, dan uji hipotesis. Berdasarkan analisis data diperoleh rata-rata t-skor untuk tes kebugaran jasmani mahasiswa Unimed 249.51 dan rata-rata t-skor untuk perolehan data mahasiswa stok sebesar 246.48. Dengan uji normalitas data perolehan mahasiswa Unimed $L_{\text {Hitung }}$ sebesar 0.1409 dan untuk perolehan data Stok adalah $L_{\text {Hitung }} 0.1121$ dengan perbandingan $L_{\text {Tabel }}$ sebesar 0.173 , maka data tersebut berdistribusi normal. Uji homongenitas sebesar $F_{\text {Hitung }} F_{\text {Tabel }}$ yaitu 1.317 $>1.980$. Hasil $u j i$ diperoleh $t_{\text {hitung }} 3.29$ dan $t_{\text {tabel }} 1,676$, sehingga hipotesis yang berbunyi terdapat perbedaan tingkat kebugaran jasmani antara mahasiswa Fakultas Ilmu Keolahragaan dan mahasiswa Sekolah Tinggi Olaharga dan Kesehatan Binaguna Angkatan 2015 dapat diterima.
\end{abstract}

Kata kunci: Kebugaran Jasmani

\section{A. PENDAHULUAN}

Pada masa sekarang ini, olahraga adalah salah satu bentuk dari upaya peningkatan kualitas manusia Indonesia yang diarahkan pada pembentukan watak, keperibadian, disiplin dan sportifitas yang tinggi, serta peningkatan kebugaran jasmani setiap individual. Olahraga adalah salah satu aktivitas yang diminati oleh masyarakat yang mana pelaksanaannya yang mudah, praktis dan juga tidak memerlukan biaya yang cukup mahal. Olahraga bertujuan untuk memperoleh kesehatan bagi tubuh dan juga untuk mendapatkan prestasi melalui cabang-cabang olahraga. 
Didalam melaksanakan kegiatan olahraga diperlukan kebugaran jasmani yang baik. Kebugaran jasmani merupakan unsur yang sanagat penting dalam kehidupan, terlebih dalam kegiatan proses belajar mengajar. Tingkat kebugaran setiap manusia pada umumnya berbeda-beda. Orang yang memiliki aktivitas lebih banyak biasanya akan lebih bugar dibandingkan dengan orang yang memiliki aktivitas yang lebih sedikit. Hal ini membuktikan bahwa aktivitas dapat mempengaruhi tingkat kebugaran.

Menurut Sajoto (1988: 43) "Kebugaran jasamani adalah kemampuan seseorang menyelesaikan tugas sehari-hari tanpa mengalami kelelahan yang berarti, dengan mengeluarkan energi yang cukup besar guna memenuhi kebutuhan geraknya dan menikmati waktu luang serta memenuhi keperluan-keperluan darurat bila sewaktuwaktu diperlukan.”

Griwijoyo (2007:17-18), mengemukakan bahwa kebugaran jasmani adalah "derajat sehat dinamis seseorang yang menjadikah kemampuan jasmani dasar untuk dapat melaksanakan tugas yang harus dilaksanakan'. Sebagai /garis besar dapat dikatakan bahwa kebugaranjasmani ialah kecocokan keadaanfisik terhadap tugas yang harus dilaksanakan oleh fisik itu. Atau dengan perkuatan lain agar dapat melaksanakan tugas fisik tertentu dengan hasil yang baik diperlukan syarat-syarat fisik tertentu yang sesuai dengan sifat fisik itu.

Departemen Pendidikan Nasional (2001:1), menyebutkan bahwa kebugaran jasmani adalah: "kemampuan tubuh seseorang untuk melakukan tugas pekerjaan seharihari tanpa menimbulkan kelelahan yang berarti". Untuk dapat mencapai kondisikebugaran jasmani yang prima seseorang melakukan latihan fisik yang melibatkan komponen kebugaran jasmani dengan metode latihan yang benar.

Kebugaran jasmani adalah kemampuan tubuh seseorang untuk melakukan tugas pekerjaan sehari-hari tanpa menimubulkan kelelahan yang berarti. Untuk dapat mencapai kondisi kebugaran jasmani yang prima seseorang perlu melakukan latihan fisik yang melibatkan komponen kebugaran jasmani dengan metode latihan yang benar.

Kebugaran jasmani terdiri dari beberapa komponen, yaitu daya tahan, daya tahan jantung dan paru-paru (cardiovascular endurance), daya tahan otot (muscle endurance), kekuatan otot (muscle strength), kelentukan (flexiblity), komposisi tubuh (body composition), kecepatan gerak (speed of movement), kelicahan (agility), keseimbangan (balance), kecepatan reaksi (reaction time), koordinasi (coordination). 
Sejumlah ahli kesehatan olahraga sependapat bahwa dari sepuluh komponen tersebut diatas, komponen data tahan jantung dan paru-paru adalah komponen terpenting dalam menentukan kebugaran jasmani seseorang. Daya tahan jantung dan paru-paru adalah suatu kemampuan tubuh untuk bekerja dalam waktu lama tanpa mengalami kelelahan setelah menyelesaikan pekerjaan tersebut. Daya tahan jantung dan paru-paru diartikan sebagai ketahanan terhadap kelelahan dan kemampuan pemulihan segera setelah mengalami kelelahan. Daya tahan yang tinggi dapat mempertahankan penampilan dalm jangka waktu yang relatif lama secara terus-menerus.

Menurut Wahjoedi (2000: 59-61), kebugaran jasmani yang berkaitan dengan kesehatan antara lain yaitu "Daya tahan jantung dan paru-paru, Kekuatan dan daya tahan otot, Kelenturan/kelentukan (Ftexibility), Komposisi tubuh, Kelincahan (Agility), Keseimbangan, Kecepatan (Speed), Koordinasi, dan Daya ledak”. Untuk lebih rinci dijelaskan di bawah ini:

1. Daya tahan jantung dan paru-paru

Menurut Wahjoedi(2000: 9), daya tahan jantung dan paru-paru kapasitas sistem jantung paru dan pembuluh darah untuk berfungsi secara optimal saat melakukan aktivitas sehari-hari dalam waktu yang cukup lama tanpa mengalami kelelahan yang berarti. Kravitz (1997: 5) mengemukakan daya tahan jantung dan paru adalah kemampuan dari jantung, paru, pembuluh darah dan paru otot yang besar untuk melakukan latihan yang keras dalam jangka waktu yang lama. Bagi mahasiswa khususnya Fakultas Ilmu Keolahragaan Universitas Negeri Medan dan Sekolah Tinggi Olahraga dan Kesehatan Bina Guna Medan, komponen ini sangat dibutuhkan untuk dapat menyelesaikan setiap mata kuliah yang sifatnya kerja fisik. Mahasiswa yang memiliki aktivitas fisik yang banyak pastinya memerlukan daya tahan kardiovaskuler yang baik pula sehingga dapat memenuhi tuntutan mata kuliah yang diberikan.

2. Kekuatan dan daya tahan otot

Kravitz (1997: 6) mengemukakan kekuatan otot adalah kemampuan otot untuk menggunakan tenaga maksimal dan mendekati maksimal untuk mengangkat beban sedangkan daya tahan otot adalah kemempuan dari otot-otot kerangka badan untuk menggunakan kekuatan tidak perlu maksimal, dalam jangka waktu tertentu".Kemudian menurut Ateng (1992: 66) "kekuatan dan daya tahan otot mengacu pada kemampuan seseorang untuk terus dapat melakukan kinerja otot yang diberi beban kerja".Jika 
seseorang memiliki daya tahan dan kekuatan otot yang baik, maka segala aktivitas baik ringan maupun berat yang dilakukan mahasiswa dapat diselesaikan dengan maksimal.

\section{Keleturan/kelentkan (Flexibility)}

Wahjoedi (2000: 60) mengemukakan "kekuatan kelenturan/kelentukan adalah kemampuan tubuh untuk melakukan gerakan melalui ruang gerak sendi atau ruang gerak tubuh secara maksimal".Selanjutnya menurut Kravitz (1997: 7) adalah "gerak otot-otot dan persendian tubuh yang berhubungan dengan kemampuan otot kerangka tubuh secara alamiah dan telah dimantapkan kondisinya diregang melampaui panjangnya yang normal waktu istirahat'. Untuk beberapa cabang olahraga tertentu, komponen ini benar-benar perlu diperhatikan, karena dalam pelaksanaannya tubuh yang dimilki kelenturan/kelentukan yang baik akan lebih mudah dalam melaksanakan sesuatu yang sifatnya cepat.

4. Komposisi tubuh

Menurut Kravitz (1997: 7), "komposisi thbüh adalah persentase lemak tubuh, dari berat badan tanpa lemak (otot, tulang rawan, dan organ vita)". Sedangkan menurut Cooper (1997) dalam Ginting dan Wijaka (2004: 35) "komposisi tubuh adalah persentase relatif dari lemak dan massa tubuh". Komposisi tubuh juga merupakan perbandingan lemak dan berat tubuh secara keseluruhan. Lapisan lemak dapat diukur dengan menggunakan Schindofold Capiler dengan bagian-bagian yang diukur adalah tricep, bicep, sub scapula, dan supraliaca.

\section{Kelincahan (Agility)}

Kelincahan adalah kemampuan seseorang untuk mengubah arah dengan cepat dan tepat pada waktu bergerak tanpa mengurangi keseimbangan.Semua cabang olahraga memerlukan komponen kebugaran ini. Maka sebagai mahasiswa khusunya olahraga, kelincahan sangat perlu untuk diperhatikan.

6. Keseimbangan

"Keseimbangan adalah kemampuan untuk mempertahankan sistem neuromuscular kita dalam kondisi statis, atau mengontrol sistem neuromuscular tersebut dalam suatu posisi atau sikap yang efisien selagi kita bergerak".(Barrow dan McGe: 1979) dalam Harsono (1988: 223). 


\section{Kecepatan (Speed)}

Harsono (1988: 216), “mengatakan bahwa kecepatan adalah kemampuan untuk melakukan gerakan sejenis secara berturut-turut dalam waktu yang sesingkatsingkatnya".

\section{Koordinasi}

"Koordinasi adalah kemampuan biometrik yang sangat kompleks. Koordinasi sangat erat hubungannya dengan kecepatan, kekuatan, daya tahan dan fleksibilitas". Bompa dalam Harsono (1988: 219)

9. Daya ledak

"Power adalah kemampuan otot untuk menggerakkan yang maksimal dalam waktu yang sesingkat-singkatnya. Power adalah hasil dari kekuatan dan kecepatan".(Harsono, 1988:176).

Kebugaran jasmani yang baik dieapai dengan latihan yang benar.Namun demikian kebugaran jasmani mempunyai faktor-faktor yang mempengaruhi sehingga tercapai kebugaran yang baik. Menurut Perry Howard (1997: $37-38$ ) faktor-faktor yang mempengaruhi kebugaran jasmani adalah: umur, jenis kelamin, bentuk badan, gizi, berat badan, istirahat, dan kegiatan jasmaniah.

Kebugaran jasmani bermanfaat untuk menciptakan citra penampilan tubuh yang bagus dipandang, membangkitkan kesan mampu melaksanakan tugas, dan percaya pada kemampuan diri serta dapat menjadikan mereka semakin cerdas dan cerah berpikir, serta siaga melaksanakan tugas (Lutan, 2007). Menurut Gabbard (1987: 50), ada dua manfaat atau maksud mengapa kita mengukur kebugaran jasmani seseorang:

a. Untuk menetahui kondisi/status kebugaran jasmani seseorang, sekaligus menentukan program latihan yang sesuai untuk memelihara atau meningkatkan kebugaran jasmani.

b. Untuk mengevaluasi keberhasilan maupun kegagalan dalam program latihan fisik. Namun, untuk mendapatkan kebugaran jasmani yang baik bukan merupakan hal yang mudah, karena harus melalui proses latihan. Latihan-latihan perlu diberikan secara menyeluruh, artinya latihan gerak yang baik adalah latihan mengikut sertakan sebanyak-banyaknya otot tubuh dan tidak dilokalisir pada otot-otot tertentu. 


\section{B. METODOLOGI PENELITIAN}

Penelitian ini dilaksanakan di Fakultas Ilmu Keolahragaan Universitas Negeri Medan Jln. William Iskandar Psr. V- Medan dan Sekolah Tinggi Olahraga dan Kesehatan Bina Guna Jln. Alumium Raya No.77 Tj. Mulia-Medan 20241. Dalam penelitian ini sampel yang diteliti sebanyak 537 orang, dengan teknik pengambilan sampel total sampling. Metode yang digunakan dalam penelitian ini adalah metode deskriptif dengan teknik pengumpulan data menggunakan tes dan pengukuran.

Penelitian ini dilakukan dengan Tes Kesegaran Jasmani Indonesia TKJI, sesuai dengan kebutuhan kebugaran jasmani mahasiswa di Fakultas Ilmu Keolahragaan Universitas Negeri Medan dan Sekolah Tinggi Olahraga dan Bina Guna, yaitu a) Lari cepat 60 meter; b) angkat tubuh 60 detik; c) berbaring duduk 60 detik; d) loncat tegak; e) lari jauh 1200 meter.

1. Tes Lari Cepat 60 Meter

a. Pelaksanaan

1) Testee berdiri dibelakakang garis strat dengan sikap strat berdiri, pada waktu diberi aba-aba "ya" testee lari kedepan secepat mungkin untuk menempuh jarak 60 meter. Pada saat testee menyentuh/melewati garis finish, stopwatch dihentikan.

2) Kesempatan lari bilamana, pelari mencuri strat, pelari berlari diluar lintasan, dan pelari terganggu oleh pelari lainnya.

2. Tes Angkat Tubuh 60 Detik

a. Pelaksanaan

1) Testee menggantung pada palang tunggal, sehingga kepala, badan dan tungkai lurus. Kedua lengan dibuka selebar bahu dan keduanya lurus.

2) Kemudian testee mangangkat tubuhnya, dengan membengkokkan kedua lengan, sehingga dagu menyentuh atau melewati palang tunggal, kemudian kembali ke sikap semula. Lakukan secara berulang-ulang tanpa beristirahat selama 60 detik.

3. Tes Baring Duduk 60 detik

a. Pelaksanaan

1) Testee berbaring terlentang di atas lantai/rumput.kedua kaki ditekuk $\pm 90^{\circ}$ kedua tangan dilipat dan diletakkan di belakang kepala, dengan 
jari tangan saling berkaitan dengan kedua tangan menyentuh lantai.

Salah seorang teman testee membantu memegang dan menekan kedua pergelangan kaki, agar kaki testee tidak terangkat.

2) Pada aba-aba "ya" teste bergerak mengambil sikap duduk, sehingga kedua sikunya menyentuh paha, kemudian kembali kesikap semula.

3) Lakukan gerakan itu berulang-ulang tanpa istirahat selama 60 detik

4) Gerakan itu gagal bilamana, kedua lengan lepas, sehingga jari-jari tidak terjalin, kedua tungkai ditekuk dengan sudut lebih dari $90^{\circ} \mathrm{dan}$ kedua siku tidak menyentuh pahak

\section{Tes Loncat Tegak}

a. Pelaksanaan

1) Testee berdiri tegak dekat dinding bertumpu pada kedua kaki dan papan didndidng berada disamping tangan kiri atau kanannya.

2) Kemudian, tangan yang berada dekat dinding diangkat lurus ke telapang tangan ditempelkan pada papan bersekala sehingga meninggalkan bekas raihannya.

Kedua tangan lurus berada disamping telinga, kemudian, testee mengambil sikap awalan membengkokkan kedua lutut dan kemudian testee setinggi mungkin sampai menepuk papan berskala dengan tangan yang terletak didinding, shingga meninggalkan bekas raihan loncataan teste tersebut

4) Testee diberi kesempatan melakukan sebanyak tiga kali loncatan.

5. Lari Jauh 1200 meter dan 1000 meter

a. Pelaksanaan

1) Testee berdiri dibelakang garis strart pada aba-aba "siap" testee mengambil sikap start berdiri untuk siap lari

2) Pada aba-aba"ya", testee lari menuju garis finish dengan menempuh jarak 1200 meter.

Data yang telah terkumpul dari tes dianalisis dengan menggunakan statistik uji-

t. adapun rumus yang digunakan adalah sebagai berikut:

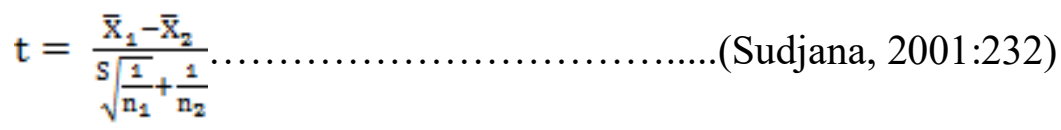




\section{HASIL DAN PEMBAHASAN PENELITIAN}

\section{Hasil}

Berdasarkan hasil penelitian, diperoleh data Tes Kebugaran Jasmani Mahasiswa FIK Unimed (X1) menyebar dari skor 199.9 sampai dengan 328.85. Berdasarkan distribusi skor tersebut diperoleh rata-rata $(\bar{X})=249.51$ dengan simpangan baku $(\mathrm{S})=$ 26.48. Distribusi frekuensi Tes Kebugaran Jasmani Mahasiswa FIK Unimed adalah seperti terlihat pada tabel 4.1 sebagai berikut

Tabel 1. Hasil Tes Kebugaran Jasmani Mahasiswa FIK UNIMED

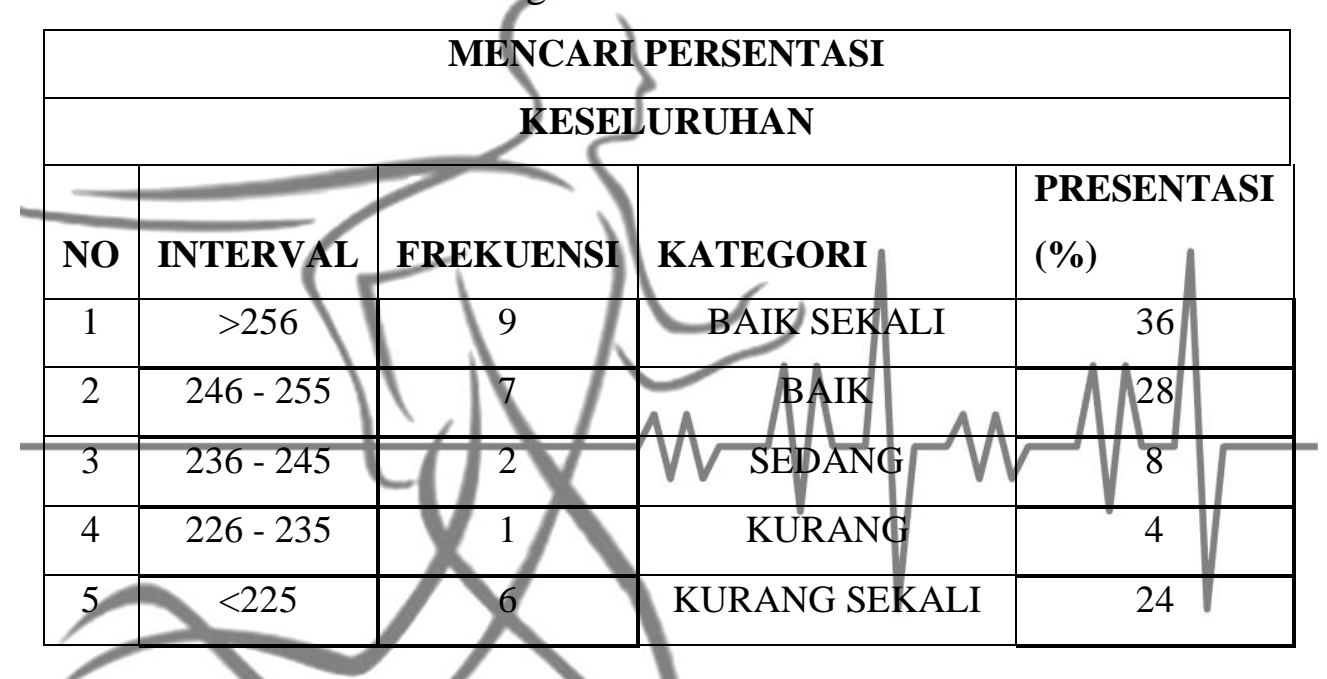

Berdasarkan hasil penelitian, diperoleh data Tes Kebugaran Jasmani Mahasiswa STOK Binaguna Medan $\left(\mathrm{X}_{2}\right)$ menyebar dari skor 153.33 sampai dengan 289.42. Berdasarkan distribusi skor tersebut diperoleh rata-rata $(\bar{X})=246.48$ dengan simpangan baku $(\mathrm{S})=30.40$. Distribusi frekuensi Tes Kebugaran Jasmani Mahasiswa STOK Binaguna adalah seperti terlihat pada tabel 4.2 sebagai berikut:

Tabel 2. Hasil Tes Kebugaran Jasmani Mahasiswa STOK Binaguna Medan

\begin{tabular}{|c|c|c|c|c|}
\hline \multicolumn{5}{|c|}{ MENCARI PERSENTASI } \\
\hline \multicolumn{5}{|c|}{ KESELURUHAN } \\
\hline NO & INTERVAL & FREKUENSI & KATEGORI & PRESENTASI (\%) \\
\hline 1 & $>259$ & 9 & BAIK SEKALI & 36 \\
\hline 2 & $248-258$ & 1 & BAIK & 4 \\
\hline 3 & $237-247$ & 8 & SEDANG & 32 \\
\hline 4 & $226-236$ & 3 & KURANG & 12 \\
\hline 5 & $<225$ & 4 & KURANG SEKALI & 16 \\
\hline
\end{tabular}


Adapun hasil perhitungan Tes Kebugaran Jasmani Mahasiswa FIK Unimed dan STOK Binaguna Medan digambarkan dalam Grafik di bawah ini:

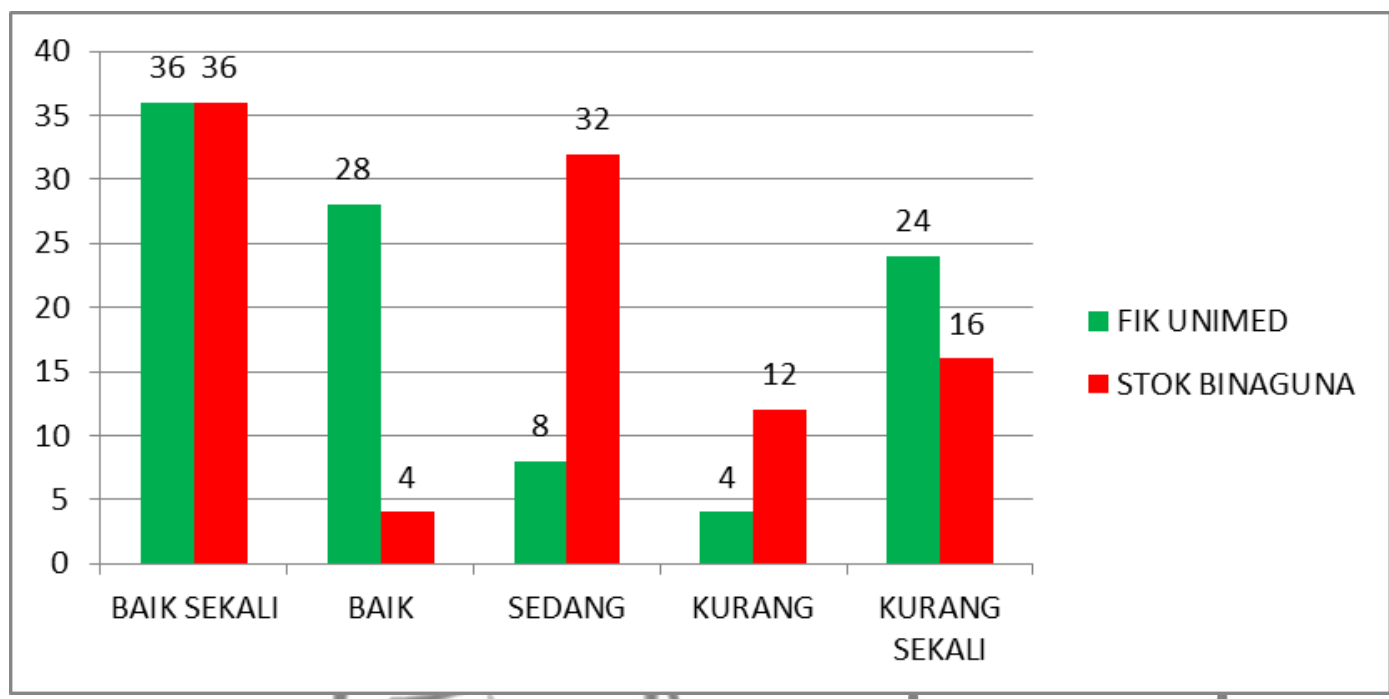

\section{Gambar 1. Hasil TKJI FIK UNIMED dan STOK Bina Guna}

Berdasarkan data tabel/dan grafik dapat disimpulkan bahwa Kebugaran Jasmani

FIK Unimed dan STOK Binaguna masuk kategori “Baik Sekali”.

\section{Pembahasan}

Pada bagian terdahulu telah diuraikan tentang hasil penelitian yang diperoleh melalui pelaksanaan tes dan pengukuran, yang selanjutnya ditunjukkuan dengan bahasan tentang hasil penelitian tersebut selanjutnya dapat disampaikan bahwa tes kebugaran jasmani (Lari 60 meter, Gantung angkat tubuh 60 detik, Baring duduk 60 detik, Loncat tegak, dan Lari 1200 meter) maka

a. Tingkat kebugaran jasmani mahasiswa Fakultas Ilmu Keolaharagaan Universitas Negeri Medan Angkatan Tahun 2015 sangat baik dengan perolehan rata-rata skor 249.51 .

b. Tingkat kebugaran jasmani mahasiswa Sekolah Tinggi Olahraga dan Kesehatan Binaguna Meda Angkatan Tahun 2015 sangat baik dengan perolehan rata-rata skor 246.48 .

c. Tingkat kebugaran jasmani mahasiswa Fakultas Ilmu Keolahragaan Universitas Negeri Medan lebih baik dibandingkan dengan tingkat kebugaran jasmani mahasiswa Sekolah Tinggi Olahraga dan Kesehatan Binaguna Medan Angkatan Tahun 2015. 
Adapun faktor yang menyebabkan perbedaan tingkat kebugaran jasmani mahasiswa Fakultas Ilmu Keolahragaan Universitas Negeri Medan dengan Sekolah Tinggi Ilmu Keolahragaan dan Kesehatan Binaguna Medan adalah matakuliah fisik FIK Unimed lebih banyak dibanding dengan matakuliah fisik STOK Binaguna, yakni FIK Unimed memiliki ada sebanyak 42 sks mata kuliah fisik dan STOK Binaguna memiliki sebanyak 36 sks mata kuliah fisik. Sehingga dapat disimpulkan bahwa aktivitas fisik FIK Unimed lebih banyak dari STOK Binaguna.

a. Kecepatan

Dalam hal ini mahasiswa FIK Unimed berada pada kategori "Baik" sedangkan mahasiswa STOK Binaguna berada pada posisi "Sedang, hal ini ditunjukan melalui-perbedaan matakuliah, FIK Unimed memiliki matakuliah fisik yang berkaitan dengan kecepatan sejumlah 16 sks diantaranya Atletik/dasar, sepak bola dasar, bola basket dasar, tenis lapangah dasar, hoki dasar, atletik lanjutan, sepak bola lanjutan. Sementra STOK Binaguna memiliki matakuliah fisik yang berkaitan dengan kecepatan sejumlah 14 sks yakni. Atletik, bulu tangkis, pembelajaran atletik, sepak bola, bola basket, futsal.

b. Kekuatan dan Daya Tahan Otot Lengan dan Bahu

Berdasarkan hasil penelitian diperoleh hasil tes Gantung Angkat Tubuh mahasiswa FIK Unimed dan STOK Binaguna dalam kategori "Baik". hal ini diperngaruhi oleh matakuliah FIK Unimed yang berkaitan dengan gantung angkat tubuh sejumlah 24 sks yakni Atletik dasar, senam dasar, renang dasar, bola voli dasar, bola basket dasar, tenis lapangan dasar, pencak silat dasar, atletik lanjutan, senam lanjutan, renang lanjutan, bola voli lanjutan, tenis lapangan lanjutan. dan STOK Binaguna yang berkaitan dengan gantung angkat tubuh sejumlah 18 sks yakni, Atletik, renang, senam, bulu tangkis, pembelajaran atletik, pembelajaran renang, pembelajaran senam, pencak silat, bola voli, bola basket.

c. Kekuatan dan Ketahanan Otot Perut

Melalui tes baring duduk mahasiswa FIK Unimed dan STOK Binaguna berada pada kategori "Sedang". Hal ini Dipengaruhi sebaran matakuliah yang diperoleh mahasiswa FIK Unimed memiliki matakuliah fisik yang berkaitan dengan Kekuatan dan Ketahanan Otot Perut sejumlah 4 sks yakni, pencak silat dasar, 
karate dasar dan STOK Binaguna memiliki matakuliah fisik yang berkaitan dengan Kekuatan dan Ketahanan Otot Perut sejumlah 4 sks yakni, pencak silat, pembelajaran pencak silat.

d. Daya Ledak

Melalui tes loncat tegak mahasiswa FIK Unimed dan STOK Binaguna berada pada kategori "Sangat Baik". Hal ini Dipengaruhi sebaran matakuliah yang diperoleh mahasiswa FIK Unimed memiliki matakuliah fisik yang berkaitan dengan Daya Ledak sejumlah 42 sks yakni: Atletik dasar, renang dasar, sepak bola dasar, bola voli dasar, bola basket dasar, tenis lapangan dasar, sepak takraw, pencak silat dasar, karate dasar, softball dasar, atletik lanjutan, senam lanjutan, renang lanjutan, sepak bola lanjutan, bola voli lanjutan, tenis lapangan lanjutan, sepak takraw lanjutan. dan STOK Binaguna memiliki matakuliah fisik yang berkaitan dengan Daya Ledak sejumtah 36 sks yakni: Atletik, renang, senam, bulu tangkis, pembelajaran atletik, pembelajaran renang, pembelajaran senam, pencak silat, sepak bola, bola voli, bola basket, pembelajaran pencak silat, pembelajaran sepak bola, pembelajaran bola basket, pembelajarn bola voli, futsal, olahraga pilihan.

e. Daya Tahan Jantung

Dalam hal ini mahasiswa FIK Unimed berada pada kategori "Baik" sedangkan mahasiswa STOK Binaguna berada pada posisi “sedang”. Hal ini Dipengaruhi sebaran matakuliah yang diperoleh mahasiswa FIK Unimed memiliki matakuliah fisik yang berkaitan dengan daya tahan jantung sejumlah 18 sks yakni Atletik dasar, sepak bola dasar, renang, bola basket dasar, tenis lapangan dasar, hoki dasar, atletik lanjutan, renang lanjutan, sepak bola lanjutan. STOK Binaguna memiliki matakuliah fisik yang berkaitan dengan daya tahan jantung sejumlah 16 sks yakni: Atletik, renang, bulu tangkis, pembelajaran atletik, pembelajaran renang, sepak bola, bola basket, futsal.

Dari pembahasan di atas dapat disimpulkan bahwa tingkat kebugaran jasmani seseorang dipengaruhi oleh aktivitas fisik yang dilakukan secara teratur dan memiliki intensitas yang baik. Kebugaran jasmani merupakan kemampuan untuk melakukan kegiatan atau pekerjaan sehari-hari dan terhadap pembebanan fisik tanpa menimbulkan kelelahan berlebihan dan masih memiliki cadangan tenaga untuk menikmati waktu 
senggang maupun pekerjaan yang mendadak serta bebas dari penyakit. Dengan aktifitas fisik yang aktif maka akan meningkatkan kebugaran jasmani yang baik.

\section{KESIMPULAN}

1. Tingkat kebugaran jasmani mahasiswa Fakultas Ilmu Keolahragaan Universitas Negeri Medan dan Sekolah Tinggi Olahraga dan Kesehatan Bina Guna angkatan Tahun 2015 kategori "Baik Sekali"

2. Tingkat kebugaran jasmani mahasiswa mahasiswa unimed dengan mahasiswa Stok sebesar 3.29. Maka dapat diambil kesimpulan terdapat perbedaan yang signifikan tingkat kebugaran jasmani antara mahasiswa Fakultas Ilmu Keolahragaan dengan Sekolah Tinggi Olahraga dan Kesehatan Bina Guna

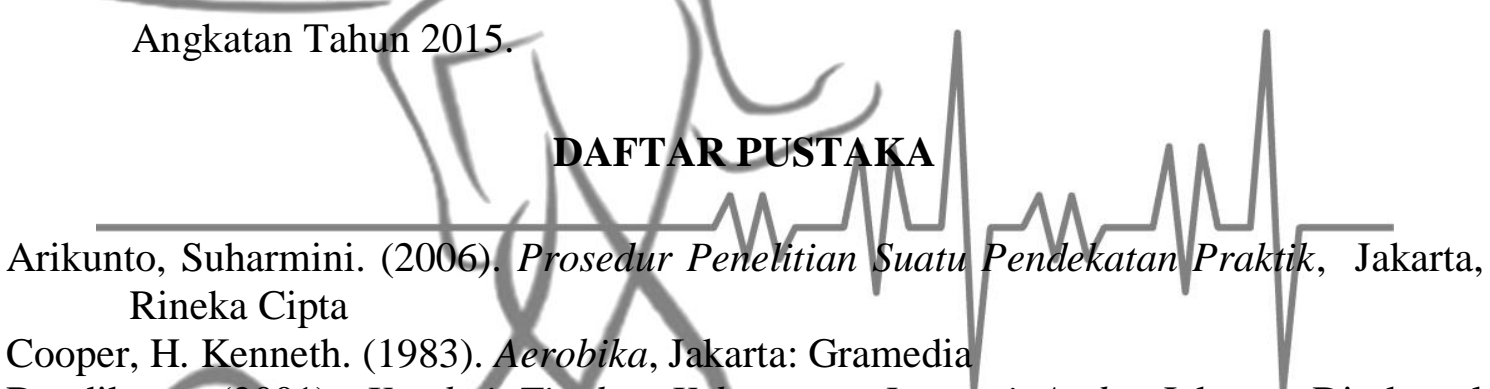

Depdiknas. (2001). Ketahui Tingkat Kebugaran Jasmani Anda, Jakarta, Direktoral Jenderal Pendidikan Tinggi Dan Kebudayaan

Griwijoyo, S. (2007).Ilmu Eaal Fisiologi (Fisiologi Olahraga). Bandung: UPI

Harsono. (1988). Dasar-Dasar Kepelatihan, Jakarta: Tambak Kusuma

Kravitz, len (1997).Bugar Total, Jakarta: Raja Gravindo

Mukholid, A. (2006). Pendidikan Jasmani. Surakarta: Yudhistira

Sajoto, M. (1988). Pembinaan Kondisi Fisik dalam Olahraga. Jakarta : Depdikbud

Sharkey, Brian J.(2006). Kebugaran Dan Kesehatan. Jakarta: Raja Gravindon Persada

Sudjana, (2001).Metoda Statistika. Bandung: Tarsito

Unimed. (2016). Buku IIIA Borang Akreditasi Program Studi Ilmu Keolahragaan Jenjang $S$-1. Medan. Kemenristek (2016). Buku VIIA Borang Akreditasi Program Studi Pendidikan Kepelatihan Olahraga Jenjang $S$-1. Medan. Kemenristek (2016). Buku VIIA Borang Akreditasi Program Studi PendidikanJasmani Kesehatan Rekreasi jenjang S-1. Medan. Kemenristek (2016). Registrasi Mahasiswa FIK Unimed T.A 2016/2017 (https://akad.unimed.ac.id/adm/cetak-buku-registrasi.php?action=print). Medan. Kemenristek

Wahjoedi, (2000).Landasan Pendidikan Jasmani. Jakarta: Raja Gravindo Persada 